\title{
Хроника
}

УДК 316.72

\section{О.В. Санникова}

О БОРЬБЕ ДВУХ КУЛЬТУР В СОВРЕМЕННОМ МИРЕ

Рецензия на книгу А.В. Меренкова «Культура эгоизма или культура сотрудничества: какая побеждает?» 1

DOI: $10.35634 / 2587-9030-2021-5-3-391-393$

\section{Правильная ссылка на статью:}

Санникова О.В. О борьбе двух культур в современном мире. Рецензия на книгу А.В. Меренкова «Культура эгоизма или культура сотрудничества: какая побеждает?» // Вестн. Удм. ун-та. Социология. Политология. Международные отношения. 2021. Т. 5, вып. 3. С. 391-393. https://doi.org/ 10.35634/ 2587-9030-2021-5-3-391-393

Монография написана на тему, которая, с одной стороны, является вечной, так как во все времена осуждался эгоизм и утверждались ценности взаимопомощи, сотрудничества при решении общих проблем, периодически возникающих у малых и больших общностей людей. С другой стороны, борьба с эгоизмом отдельных индивидов, социальных групп не привела к торжеству принципов заботы об общем благе. Более того, как указывает автор в предисловии, масштабы его проявления настолько возросли, «что уже политики заявляют о том, что эгоизм является причиной возрастания конфронтации между странами в экономической, политической сфере, трудностей решения экологических проблем» (С. 5).

В книге раскрываются источники возникновения и утверждения ценностей эгоизма и противоположных ему норм сотрудничества на основе рассмотрения этих явлений с позиций культуры. Доказывается, что в течение всей истории человечества происходило формирование и развитие двух разных по направленности и содержанию культур. Действовали особые механизмы, обеспечивающие приобщение личности, социальных групп к той или другой культуре. В современном динамично меняющемся обществе существенно возросла активность субъектов, заинтересованных в удовлетворении в первую очередь своих интересов, пренебрегая потребностями других людей.

В первом разделе монографии представлено несколько основных положений, раскрывающих методологию анализа культуры эгоизма и культуры сотрудничества. Прежде всего утверждается идея о необходимости выделения природной основы их существования. Это положение до сих пор не выступает в качестве базового при трактовке в социальных науках специфики культурной деятельности человека. Опираясь на работы социальных антропологов, социобиологов, психологов, автор приходит к выводу, что культура направлена на усиление или ослабление действия природных инстинктов, наследуемых человеком от животных в процессе эволюции (С. 22). Система семейного, общественного образования, воспитания способна решить задачи преодоления эгоизма, если обеспечивает включение детей с раннего детства в посильный для них труд в интересах семьи, жителей поселка, города, страны, формируя установки на заботу о других людях, приобретение необходимых для этого моральных качеств.

Следующая идея связана с пониманием сущности и способов распространения исследуемых автором культур. «Культура эгоизма формируется в деятельности, направленной на создание, сохранение, умножение сочиальных различий, возникающих между людьми в результате владения разными по объему материальными благами, властными полномочиями. Утверждается в качестве главной ценности умение использовать любые методы повышения социального статуса, обогащения, завоевания и сохранения власти» (С. 27).

«Культура сотрудничества создается в процессе совместной деятельности социальных субъектов, руководствующихся общими целями, интересами, а не частными потребностями ее участников. Появ-

\footnotetext{
${ }^{1}$ Меренков А.В. Культура эгоизма или культура сотрудничества: какая побеждает? Монография. Екатеринбург: Изд-во Урал. ун-та. 2021. $276 \mathrm{c.}$
} 
ляются условия для формирования и развития у каждого индивида способности самостоятельно подавлять эгоистические инстинкты, усиливая установки на заботу о тех, кто нуждается в ней» (С. 35).

Важным положением работы является деление носителей культуры эгоизма на самовозвышающихся и самоунижающихся. Те и другие используют схожие методы решения противоположных целей. Для первых хитрость, обман, психическое, физическое давление являются средствами получения материальных преимуществ, власти. Для вторых этими способами обеспечивается возможность сохранить свою жизнь, получить возможность удовлетворить элементарные потребности, постоянно занимаясь нередко тяжелым трудом. В монографии раскрываются экономические, политические факторы утверждения и развития культуры эгоизма на протяжении всей истории человечества.

Автор показывает, что освоение личностью культуры эгоизма часто происходит без специального обучения и воспитания. Люди бессознательно используют заложенные природой способы получения желаемого хитростью, обманом, психическим, физическим давлением, изобретая новые на основе достижений науки, техники. Приобщение к культуре сотрудничества требует развития сознания человека в процессе осмысления целей, смыслов, конечных результатов предпринимаемых действий. Необходима постоянная борьба с эгоистическими побуждениями, периодически возникающими у каждого человека при умелом согласовывании собственных интересов с потребностями других людей. Анализируется противоречивая роль религии и государства в формировании культуры сотрудничества.

В работе исследуются механизмы формирования ориентаций личности на принятие ценностей культуры эгоизма или культуру сотрудничества. Показано, как с раннего детства в процессе воспитания, включающего в качестве обязательного компонента совместный с окружающими людьми труд, осуществляется выработка нормативной гордости, стыда, совести, долга, ответственности. Когда ребенок получает какие-либо блага без собственных усилий, навязывая свою волю окружающим, у него формируются самоуверенность, чувство превосходства, желание всевластия. Раскрывается роль семьи, школы, средств массовой информации, искусства, литературы в использовании механизмов приобщения к той или иной культуре при социализации подрастающего поколения. Отмечается, что субъекты, занимающиеся обучением, воспитанием личности, не всегда задумываются о том, как их мысли, высказывания, поступки влияют на утверждение установок на индивидуализм, стремление хитростью, обманом возвыситься над другими людьми. Выделяются трудности, которые существуют в настоящее время при выработке у детей, подростков ориентаций на освоение ценностей культуры сотрудничества.

Социолог не дает готового ответа не поставленный в заголовке книги вопрос о том, какая культура побеждает в наше время. В последней части работы анализируются проблемы, возникающие в условиях автоматизации производства, появления устройств с искусственным интеллектом, которые требуется решить при утверждении ценностей культуры сотрудничества. Предложены способы изменения воспитания детей в семье, организации трудовой деятельности в производственных коллективах, местного управления, способствующие утверждению в сознании подавляющего большинства людей ориентаций на взаимопомощь, поддержку, реализацию общих интересов, что является условием повышения качества жизни каждого человека.

Работа носит междисциплинарный характер, некоторые положения, выводы побуждают к дискуссии, что повышает ее научную ценность.

Поступила в редакцию 24.06.2021

Санникова Ольга Владимировна, доктор социологических наук, доцент, профессор кафедры социологии ФГБОУ ВО «Удмуртский государственный университет» 426034, Россия, г. Ижевск, ул. Университетская, 1 (корп. 6)

E-mail: alexbor@udm.ru

\section{O.V. Sannikova}

ABOUT THE STRUGGLE OF TWO CULTURES IN THE MODERN WORLD

Review of the book by A.V. Merenkov "The culture of egoism or the culture of cooperation: which one wins?" 


\section{For citation:}

Sannikova O.V. About the struggle of two cultures in the modern world. Review of the book by A.V. Merenkov "The culture of egoism or the culture of cooperation: which one wins?" // Bulletin of Udmurt University. Sociology. Political Science. International Relations. 2021. Vol. 5, iss. 3. P. 391-393. https://doi.org/10.35634/2587-9030-2021-5-3-391393 (In Russ.).

Sannikova O.V., Doctor of Sociology, Associate Professor, Professor at Department of Sociology Udmurt State University

Universitetskaya st., 1/6, Izhevsk, Russia, 426034

E-mail: alexbor@udm.ru 